\title{
The Complex Network between MYC Oncogene and microRNAs in Gastric Cancer: An Overview
}

\author{
Ana Carolina Anauate 1,2®D, Mariana Ferreira Leal ${ }^{1}$, Danielle Queiroz Calcagno ${ }^{3}$, \\ Carolina Oliveira Gigek ${ }^{1,4}$, Bruno Takao Real Karia ${ }^{1}$, Fernanda Wisnieski ${ }^{1,5}$, \\ Leonardo Caires dos Santos ${ }^{1}$, Elizabeth Suchi Chen ${ }^{1} \mathbb{C}$, Rommel Rodríguez Burbano ${ }^{3,6,7}$ and \\ Marília Arruda Cardoso Smith ${ }^{1, *}$ \\ 1 Disciplina de Genética, Departamento de Morfologia e Genética, Universidade Federal de São Paulo, \\ São Paulo SP 04023-062, Brazil; anauatte@gmail.com (A.C.A.); lealmf@gmail.com (M.F.L.); \\ carolina.gigek@unifesp.br (C.O.G.); brunokaria@gmail.com (B.T.R.K.); f.wisnieski@unifesp.br (F.W.); \\ caires.leonardo@unifesp.br (L.C.d.S.); eschen@unifesp.br (E.S.C.) \\ 2 Disciplina de Nefrologia, Departamento de Medicina, Universidade Federal de \\ São Paulo, São Paulo SP 04023-062, Brazil \\ 3 Núcleo de Pesquisas em Oncologia, Hospital Universitário João de Barros Barreto, Universidade Federal do \\ Pará, Belém PA 66075-110, Brazil; danicalcagno@gmail.com (D.Q.C.); rommel@ufpa.br (R.R.B.) \\ 4 Departamento de Patologia, Universidade Federal de São Paulo, São Paulo SP 04023-062, Brazil \\ 5 Disciplina de Gastroenterologia, Departamento de Medicina, Universidade Federal de São Paulo, \\ São Paulo SP 04023-062, Brazil \\ 6 Laboratório de Citogenética Humana, Instituto de Ciências Biológicas, Universidade Federal do Pará, \\ Belém PA 66075-110, Brazil \\ 7 Laboratório de Biologia Molecular, Hospital Ophir Loyola, Belém PA 66063-240, Brazil \\ * Correspondence: macsmith@unifesp.br; Tel.: +55-11-5576-4848
}

Received: 18 December 2019; Accepted: 25 February 2020; Published: 5 March 2020

\begin{abstract}
Despite the advancements in cancer treatments, gastric cancer is still one of the leading causes of death worldwide. In this context, it is of great interest to discover new and more effective ways of treating this disease. Accumulated evidences have demonstrated the amplification of 8q24.21 region in gastric tumors. Furthermore, this is the region where the widely known MYC oncogene and different microRNAs are located. MYC deregulation is key in tumorigenesis in various types of tissues, once it is associated with cell proliferation, survival, and drug resistance. microRNAs are a class of noncoding RNAs that negatively regulate the protein translation, and which deregulation is related with gastric cancer development. However, little is understood about the interactions between microRNAs and MYC. Here, we overview the MYC role and its relationship with the microRNAs network in gastric cancer aiming to identify potential targets useful to be used in clinic, not only as biomarkers, but also as molecules for development of promising therapies.
\end{abstract}

Keywords: gastric cancer; microRNA; 8q24.21; MYC; target therapy

\section{Introduction}

Gastric cancer (GC) is one of the most common cancers worldwide, and its incidence is very high mainly in Eastern Asia, Eastern Europe, and South America [1,2]. In 2018, the Global Cancer Observatory (GLOBOCAN) estimated 1,033,701 new cases of stomach neoplasms worldwide, representing 5.7\% of all new cases of cancer. Additionally, gastric tumors were expected to be the 3rd cause of cancer related death among males and the 5th among females, evidencing that GC is more likely to be diagnosed in males than in females. Collectively, between men and women, stomach cancer was predicted to correspond to 782,685 deaths and be the 7th most prevalent neoplasm. Moreover, for 2018, globally, 
the risk of developing stomach cancer was $1.87 \%$ in men and $0.79 \%$ in women. While the risk of dying because of stomach cancer was $1.36 \%$ for males and $0.57 \%$ for females [3]. GC is an aggressive disease commonly diagnosed at advanced stages, and surgical resection associated with chemotherapy or chemoradiation is considered the main treatment option for GC [4]. The etiology of GC is multifactorial including environmental factors, such as Helicobacter pylori (H. pylori) infection [5] and Epstein-Barr virus infection [6], dietary factors [7,8], high consumption of alcohol [9], smoking [10], as well as genetic factors [11], and epigenetic alterations [12,13].

Chromosome 8 regions are frequently amplified in GC samples, especially the 8q24.21 region [14-17]. Among the coding genes present in this region, the most studied is MYC (also named c-MYC; Figure 1), and the literature shows that its activation can contribute to tumorigenesis [18-20]. MYC amplification and its upregulated expression have been commonly observed in GC cell lines and GC tissues, and the highest MYC levels have been reported in the tumors of patients with local or distant metastasis [14,17,21-29]. The key role of MYC in GC etiology was further confirmed in a nonhuman primate model, where both MYC expression and copy number were continuously increased during the sequential steps of intestinal-type gastric carcinogenesis [26]. Indeed, MYC not only has a key role in gastric carcinogenesis but is also one of the most robust and significant prognostic markers of GC [16]. For this reason, further topics will explore more of this role.

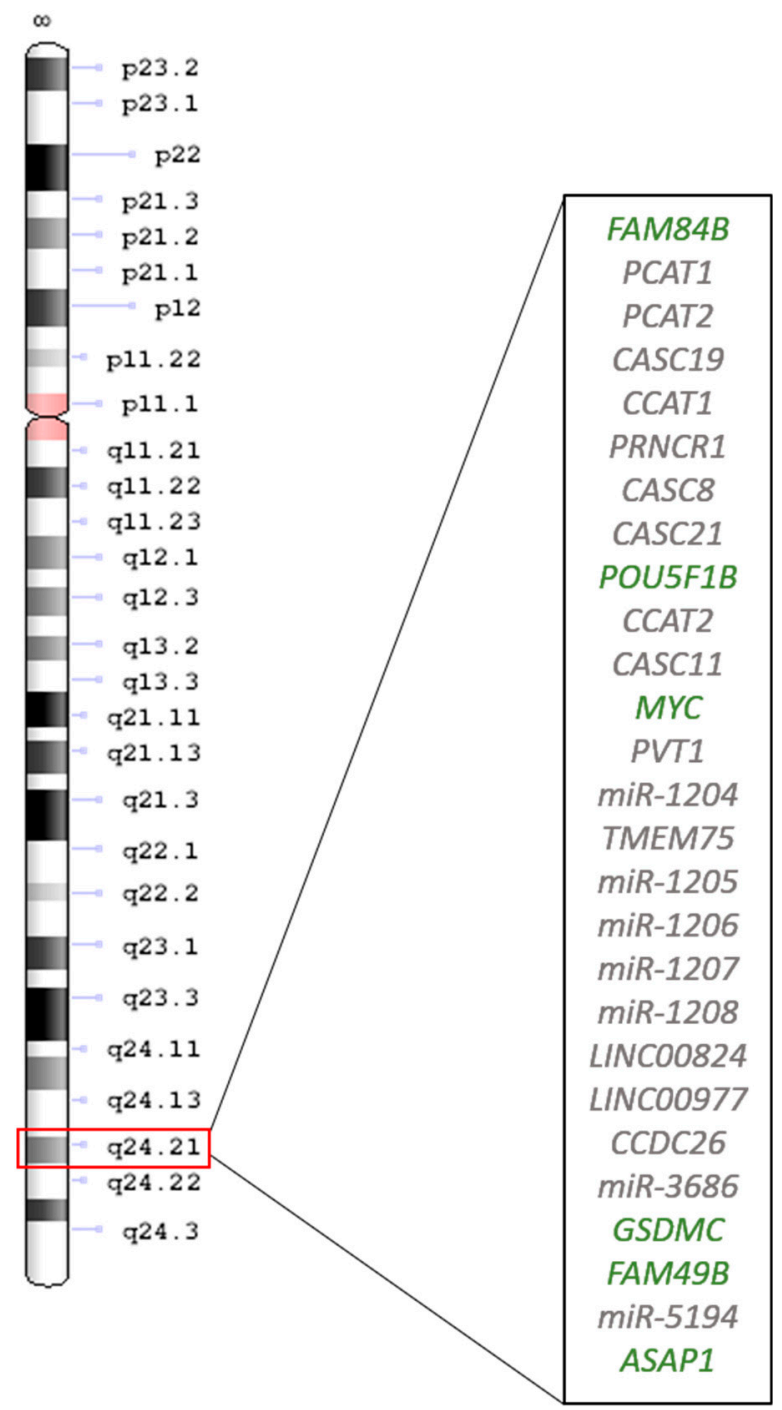

Figure 1. The 8q24.21 genes. The coding genes are shown in green, and the non-coding genes in grey. 
It is worth mentioning other coding and noncoding genes of 8q24.21, shown in Table 1. Among them, the plasmacytoma variant translocation 1 (PVT1) oncogene encodes a long noncoding RNA (lncRNA). Compared with MYC, PVT1 is less studied, but it is involved in critical processes in cancer cells, including DNA rearrangements, genetic instability, microRNA (miRNA) encoding, and also interacts with MYC itself [30-33]. Increased PVT1 expression was shown to induce cell proliferation and migration in GC cell lines, and it was previously associated with higher cell invasion, advanced stages, and poor prognosis in GC patients [34-36]. Besides PVT1, the CASC11 noncoding gene is highly expressed in GC tissues and cell lines, and its knockdown inhibits cancer progression [37-42].

Table 1. Genes localized at 8q24.21 region.

\begin{tabular}{|c|c|c|c|}
\hline Gene & Gene Name & Expression in GC & Reference \\
\hline \multicolumn{4}{|c|}{ Coding genes } \\
\hline FAM84B & Family with sequence similarity 84 , member B & $?$ & \\
\hline POU5F1B & POU domain, class 5, transcription Factor 1B & $\begin{array}{l}\text { Down } \\
\text { Up }\end{array}$ & {$[42]$} \\
\hline$M Y C$ & MYC proto-oncogene & Up & {$[14,16,21,22,24-27,43-45]$} \\
\hline GSDMC & Gasdermin C & $?$ & \\
\hline FAM49B & Family with sequence similarity 49 member B & ? & \\
\hline$A S A P 1$ & $\begin{array}{l}\text { ArfGAP with SH3 domain, ankyrin repeat and } \\
\text { PH domain } 1\end{array}$ & ? & \\
\hline \multicolumn{4}{|c|}{ Noncoding genes } \\
\hline CASC 8 & Cancer susceptibility candidate 8 & ? & [46] \\
\hline CASC11 & Cancer susceptibility candidate 11 & Up & [37] \\
\hline CASC21 & Cancer susceptibility candidate 21 & $?$ & \\
\hline CASC19 & Cancer susceptibility candidate 19 & ? & \\
\hline CCAT1 & Colon cancer-associated transcript 1 & Up & {$[38,39]$} \\
\hline CСAT2 & Colon cancer-associated transcript 2 & Up & [40] \\
\hline LINC00824 & Long intergenic non-protein coding RNA 824 & $?$ & \\
\hline LINC00977 & Long intergenic non-protein coding RNA 977 & ? & \\
\hline miR-1204 & MicroRNA 1204 & ? & \\
\hline miR-1205 & MicroRNA 1205 & Did not differ & [47] \\
\hline miR-1206 & MicroRNA 1206 & $?$ & \\
\hline miR-1207 & MicroRNA 1207 & Did not differ & [47] \\
\hline miR-1208 & MicroRNA 1208 & Did not differ & [47] \\
\hline miR-5194 & MicroRNA 5794 & $?$ & \\
\hline miR-3686 & MicroRNA 3686 & ? & \\
\hline CCDC26 & Coiled-coil domain-containing protein 26 & ? & \\
\hline TMEM75 & Transmembrane protein 75 & ? & \\
\hline PCAT1 & Prostate cancer-associated transcript 1 & ? & \\
\hline PCAT2 & Prostate cancer-associated transcript 2 & ? & \\
\hline PRNCR1 & Prostate cancer associated noncoding RNA 1 & $?$ & [48] \\
\hline PVT1 & $\begin{array}{l}\text { Plasmacytoma variant translocation } 1, M Y C \\
\text { activator }\end{array}$ & Up & [49] \\
\hline
\end{tabular}

GC: gastric cancer; Up, upregulated expression in gastric cancer in relation to control; Down, downregulated expression in gastric cancer in relation to nonneoplastic samples; Did not differ, expression in gastric cancer did not differ in relation to nonneoplastic samples; ?: absence of studies on direct relationship between the respective microRNA and MYC in gastric cancer.

Some miRNAs (Table 1) were also identified in the 8q24.21 region. miRNA is a molecular class of small noncoding RNA of approximately 22 nucleotides that regulate gene expression through sequence complementarity with the target mRNA. miRNA genes are transcribed into primary miRNA transcripts and subsequently processed by the RNase III enzyme Drosha inside the nucleus, releasing 60-110-nucleotide pre-miRNA hairpins. The pre-miRNA is then exported into the cytoplasm by Exportin-5, where it is cleaved by Dicer into 22-nucleotide double-stranded miRNAs. Finally, miRNAs regulate the expression of their mRNA targets when the multiprotein RNA-induced silencing complex (RISC) is formed [50]. In this process, total complementarity results in the cleavage of the mRNA target strand, while imperfect complementarity leads to repression of the mRNA translation [51]. Thus, unsurprisingly, miRNA deregulation has been described in different diseases, including GC [47,52], and this deregulation may help us elucidate critical pathways involved in carcinogenesis processes and identify potential prognostic or predictive biomarkers [53-56]. 
Notably, a variety of miRNAs can also directly or indirectly regulate MYC expression $[57,58]$. Therefore, the complex interaction between MYC and miRNAs still needs to be further understood. This review updates and illustrates the oncogenic role of $M Y C$ in gastric carcinogenesis and its association with $H$. pylori infection, highlighting the network with miRNAs.

\section{Biological Significance of $M Y C$}

The MYC family is a group of cellular proto-oncogenes with the following three highly related nuclear phosphoproteins: MYC, N-MYC, and L-MYC [59]. MYC has a low expression and has a short half-life in normal cells, and its mRNA level is tightly regulated by both transcriptional and post-transcriptional mechanisms [60]. However, it is overexpressed in several neoplasms. Our group and others have shown $M Y C$ overexpression in GC samples [17,43,44], including early stages [23,61], and reported MYC protein overexpression [23,24]. Moreover, other studies revealed the importance of the co-amplification of MYC and EGFR and FGFR2, in predicting poor survival of patients undergoing cancer therapy [62]. In tumor cells, MYC activation occurs as follows: (1) mutations in signaling pathways proteins upstream from MYC; (2) mutations and single nucleotide polymorphisms in regulatory regions that enhance the stability of these proteins [63] and (3) direct modification of $M Y C$ gene via gene amplification, mutation, chromosomal translocation and epigenetic modifications [24,63-65].

MYC deregulation plays an important role in neoplastic development by targeting genes involved in critical cellular functions, such as DNA metabolism and dynamics, cell cycle, apoptosis, adhesion, survival, and protein and macromolecular synthesis $[60,66,67]$. Moreover, it contributes to aerobic metabolism by activating the expression of several genes essential for glycolysis and mitochondrial biogenesis [68]. Additionally, its hyperactivity can allow widespread miRNAs downregulation through the regulation of transcriptional and post-transcriptional mechanisms. Indeed, $M Y C$ is known as the gene with the highest interaction with downregulated miRNAs [69-71]. Taken together, this scenario shows that MYC deregulation (usually overexpression) can have an impact in various cellular functions, contributing to an abnormal cell growth (Figure 2) [68,72].

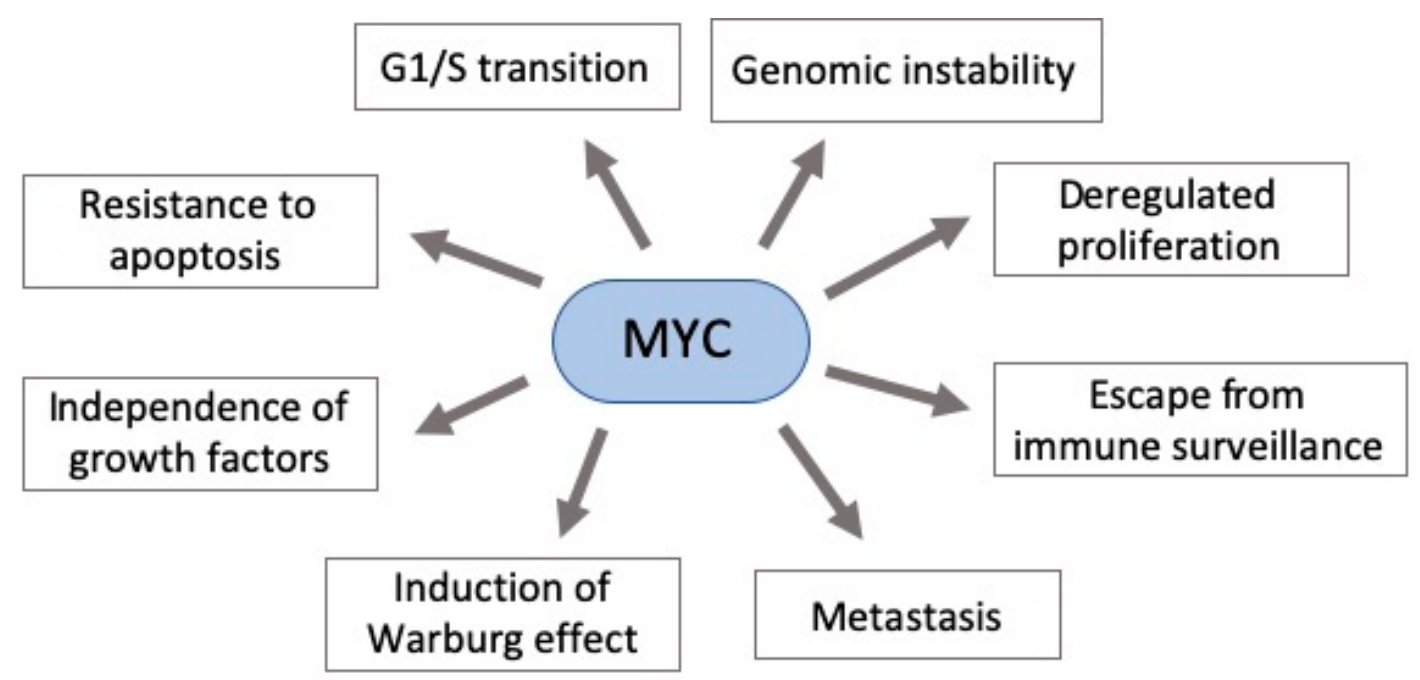

Figure 2. Pleiotropic consequence of MYC deregulation in cancer. MYC overexpression in gastric carcinogenesis affects various components of signaling pathways critical to cancer establishment. Some of these pathways' phenotypes are shown here.

Infectious agents are extremely important factors on cancer development, accounting for $16 \%$ of all new cancer cases per year worldwide [73]. Moreover, liver and gastric tumors in men account for greater than $80 \%$ of the infection-related burden cancers [73]. According to the International Agency for Research on Cancer (IARC), 78\% of all GC cases are estimated to be associated to chronic $H$. 
pylori infection, a bacteria classified as a group 1 carcinogen [74]. The virulence of this bacterium is commonly determined by cag $A$ and vacA genes. The $c a g A$ gene encodes the secretion complex, capable of introducing the cagA oncoprotein in the gastric epithelial cell, which activates mitogen-activated protein (MAP) kinases. This alteration activates cell proliferation, differentiation, and stress and inflammatory responses and inhibits programed death, leading to a precancerous process [75,76]. Especially in intestinal-type of GC, H. pylori cagA has been associated with increased MYC expression and nuclear MYC protein [77,78]. In H. pylori infected patients with active gastritis, chromosomal aneuploidy and cellular DNA damage were associated with MYC expression, leading to a chronic hyperproliferation [79]. This association may occur through $H$. pylori-induced activation of NF- $\mathrm{kB}$ and AP-1 proteins which transcriptionally regulate $\beta$-catenin expression, responsible for controlling $M Y C$ expression and consequently cell proliferation $[67,80]$. On the other hand, MYC overexpression was not observed in patients without $H$. pylori infection [79].

The alteration of the DNA methylation profile is considered to be associated with the H pylori inflammatory response, rather than the infection itself [81]. This infection participates in the regulation of MYC expression, which is necessary to gastric carcinogenesis occur (Figure 3), but its infection alone is insufficient to the disease establishment. Thus, the identification of molecules and miRNAs associated with $H$. pylori infection in GC can contribute to understand the key cellular and molecular processes at the beginning of carcinogenesis and how environmental factors contribute to GC etiology.

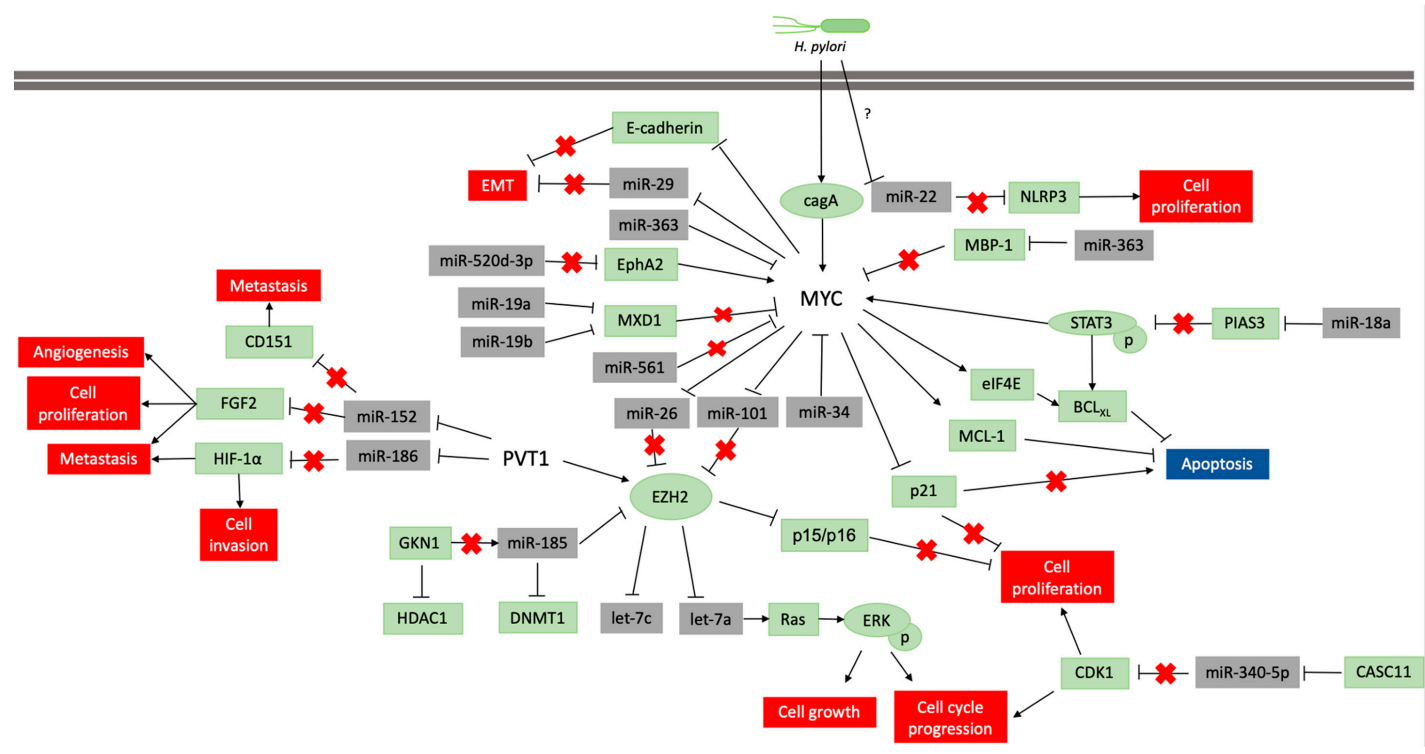

Figure 3. Pathways scheme in which miRNAs regulate MYC and PVT1 expression and vice versa in neoplastic gastric tissue samples and cell lines. The coding genes are shown in green, and the non-coding genes in grey. Lines ending with an arrow indicate activation, whereas $\mathrm{T}$ ending lines indicate repression. Lines with a red cross indicate that the interaction is lost due to repression or blocking of a miRNA or protein.

\section{The Complex Relationship between microRNAs and MYC Expression}

The deregulation of the expression of several miRNAs can directly or indirectly lead to increased or decreased $M Y C$, (Table 2). As described above, MYC plays a key role in the normal and tumor development, and the MYC/miRNA network is likely to contribute to the oncogenic functions of MYC. In the present review, we highlight some miRNAs that are altered in GC and are associated with MYC activation. 
Table 2. Deregulated miRNAs associated directly or indirectly with MYC expression in gastric cancer.

\begin{tabular}{|c|c|c|c|c|}
\hline \multicolumn{2}{|c|}{ miRNA } & $\begin{array}{c}\text { miRNA } \\
\text { Expression }\end{array}$ & MYC Expression & Reference \\
\hline \multirow{3}{*}{\multicolumn{2}{|c|}{$\begin{array}{c}m i R-9 \\
m i R-15 a / 16-1 \\
m i R-25\end{array}$}} & $\mathrm{Up}$ & Up & {$[82,83]$} \\
\hline & & Down & Up & {$[84,85]$} \\
\hline & & Up & Up & {$[86,87]$} \\
\hline \multirow{10}{*}{ Cluster miR-17-92 } & $m i R-17$ & $\mathrm{Up}$ & $\mathrm{Up}$ & {$[87,88]$} \\
\hline & $m i R-18 a$ & Up & $\mathrm{Up}$ & {$[87,89]$} \\
\hline & miR-19a/miR-19b & Up & $\mathrm{Up}$ & {$[87,90]$} \\
\hline & miR-20 & $\mathrm{Up}$ & $?$ & [87] \\
\hline & $m i R-22$ & Down & $?$ & [91] \\
\hline & $m i R-26$ & Down & $\mathrm{Up}$ & [92] \\
\hline & $m i R-29$ & Down & $?$ & [93] \\
\hline & $m i R-33 b$ & Down & Down & [94] \\
\hline & $m i R-34 a$ & Down & $\mathrm{Up}$ & {$[95,96]$} \\
\hline & $m i R-92$ & Down & $?$ & [97] \\
\hline \multicolumn{2}{|c|}{ miR-93 } & Up & Down & [98] \\
\hline \multicolumn{2}{|c|}{$m i R-101$} & Down & Up & [99] \\
\hline \multicolumn{2}{|c|}{ miR-106a/miR-106b } & $\mathrm{Up}$ & $?$ & {$[87,100]$} \\
\hline \multicolumn{2}{|c|}{$m i R-150$} & Down & $\mathrm{Up}$ & [101] \\
\hline \multicolumn{2}{|c|}{ miR-152 } & Down & & [102] \\
\hline \multicolumn{2}{|c|}{ miR-185 } & Down & $\mathrm{Up}$ & [103] \\
\hline \multicolumn{2}{|c|}{$m i R-186$} & Down & $?$ & [104] \\
\hline \multicolumn{2}{|c|}{$m i R-200 c$} & Down & $?$ & [105] \\
\hline \multicolumn{2}{|c|}{ miR-212 } & Up & $\mathrm{Up}$ & [106] \\
\hline \multicolumn{2}{|c|}{$m i R-363$} & Down & $\mathrm{Up}$ & [106] \\
\hline \multicolumn{2}{|c|}{$m i R-374$} & $\mathrm{Up}$ & $?$ & [107] \\
\hline \multicolumn{2}{|c|}{$m i R-429$} & Down & $\mathrm{Up}$ & [108] \\
\hline \multicolumn{2}{|c|}{$m i R-494$} & Down & $\mathrm{Up}$ & [109] \\
\hline \multicolumn{2}{|c|}{$m i R-520 d-3 p$} & Down & $\mathrm{Up}$ & [110] \\
\hline \multicolumn{2}{|c|}{$m i R-561$} & Down & $\mathrm{Up}$ & [111] \\
\hline \multicolumn{2}{|c|}{ miR-935 } & Up & $\mathrm{Up}$ & [112] \\
\hline \multicolumn{2}{|c|}{ miR-1284 } & Down & $?$ & [113] \\
\hline \multicolumn{2}{|c|}{ let-7a } & Up & $\mathrm{Up}$ & [114] \\
\hline
\end{tabular}

Up, upregulated expression in gastric cancer in relation to control; Down, downregulated expression in gastric cancer in relation to control; ?: absence of studies on direct relationship between the respective microRNA and MYC in gastric cancer.

\subsection{MYC Is Regulated by Epigenetic Modifications}

Epigenetic modifications are involved in most cellular biological processes by the regulation of coding and noncoding gene expression. The term epigenetic is defined as heritable modifications in gene expression with no change in the sequence of DNA nucleotides. Notably, MYC and miRNAs expressions are regulated by epigenetic mechanisms, such as promoter methylation and histone acetylation. For instance, miR-212 expression is downregulated by its promoter methylation in GC patient tissues and cell lines. MYC mRNA expression is upregulated upon mir-212 knockdown. Additionally, experiments using wild type and mutant miR-212 mimics and luciferase activity assays confirmed that MYC is a target of $m i R-212$ [115]. Another example is $m i R-33 b$, which is downregulated in GC, and its expression can also be inhibited by the hypermethylation of its promoter [116]. Additionally, ectopic expression of $m i R-33 b$ inhibits tumorigenesis in vitro and in vivo by directly targeting MYC, indicating that this miRNA plays a tumor suppressor role in GC (Table 2) [116]. Hayashi et al. showed that the aforementioned $H$. pylori cagA inhibits let-7 expression and enhances the expression of MYC DNA methyltransferase 3B (DNMT3B) and Enhancer of Zeste homologue 2 (EZH2). As a result, let-7 expression was decreased due to methylation of its promoter and increased H3K27 trimethylation [77]. MiR-448 is another miRNA reported to control MYC expression by epigenetic modifications. Hong et 
al. showed that miR-448 expression is up-regulated in GC cell lines and patient samples compared to a normal gastric mucous cell line and paired non-tumor tissues. The overall survival and the time to relapse of GC patients with higher miR-448 expression was reported shorter when compared with the GC patients with low $m i R-448$. Consistently, the group of GC tumors with high $m i R-448$ expression was associated with poor histological differentiation, tumor size and distant metastasis. In vitro and in vivo experiments demonstrated that miR-448 promotes proliferation by repressing KDM2B (Lysine Demethylase 2B) stimulating glycolysis. Furthermore, KDM2B was shown to be bound to MYC promoter inhibiting its expression, demonstrating that KDM2B suppression by $m i R-448$ is essential for the overexpression of MYC expression in GC [117]. A study by Choi et al. revealed that MiR-185 and GKN1 (Gastrokine 1) expression levels were reduced in gastric mucosal samples, while protein expression levels of DNMT1, EZH2, and MYC were higher in these samples. Analysis of CpG island methylation showed that mir-185 and GKN1 promoters are highly methylated, whereas DNMT1, EZH2, and MYC promoters are less methylated. Suggesting that mir-185 may regulate DNMT1,EZH2, and MYC expression [118]. Collectively, these data suggest that besides epigenetic alterations in its gene, MYC expression is also influenced by epigenetic alterations in miRNAs genes.

\subsection{MicroRNAs Regulate MYC Oncogenic Pathways}

MYC is involved in several pathways in gastric tumor cells (Figure 2), and manifold miRNAs may interfere with them, such as miR-494, miR-429, miR-520d-3p, miR-363, miR-561 and the aforementioned $m i R-33 b$. In GC, miR-494 and miR-429 are downregulated, and negatively correlated with MYC expression. The overexpression of miR-494 decreased MYC expression, the number of viable cancer cells, tumor burden, and the percentage of proliferative cells [109], and cells transfected with miR-429 showed downregulation of MYC protein [108]. miR-520d-3p, which is also downregulated in GC tissue and cell lines, inhibited the expression of EphA2 (Ephrin Receptor A2), a gene involved in nervous system development. Additionally, cells transfected with mimic miR-520d-3p showed lower MYC and EphA2 expression and diminished cell proliferation, invasion, and migration [110,119]. miR-363 promotes GC progression through MBP-1 inhibition, leading to an upregulation of MYC protein expression [106]. miR-561 is also downregulated in human GC cell lines and tissues, and its expression was associated with tumor-node-metastasis (pTNM) staging system and suppressed MYC expression by directly binding to its $3^{\prime}$-untranslated region [111]. This research group demonstrated that $m i R-561$ can act as a tumor suppressor miRNA in GC by targeting $M Y C$ and inhibiting cellular proliferation and invasion. All together these results suggest that these miRNAs can be used as targets for new treatment strategies against GC.

Several studies revealed that the miR-29 family $(m i R-29 a-c)$ was inversely correlated with MYC expression and regulates cell growth and survival by targeting CDK6 (Cell division protein kinase 6), IGF1R (Insulin Like Growth Factor 1 Receptor), TCL1 (T-cell leukemia/lymphoma protein 1A), PI3K (Phosphoinositide 3-kinase) and MCL1 (Induced myeloid leukemia cell differentiation protein) [120-122]. However, Gong et al. found that miR-29 suppresses GC cell proliferation or invasiveness by targeting the cell cycle G1/S transition gene Cyclin D2 (CCND2) or MMP2 (matrix metallopeptidase 2), which encodes for an enzyme that degrades extracellular matrix [122]. The mechanism is unknown yet, but it is well established that MYC directly suppresses miR-29 [120,123]. As reported by Yan et al., miR-29b is recognized as an essential regulator of epithelial-mesenchymal transition (EMT) and is directly involved in cancer metastasis and chemoresistance [124]. Moreover, Saito and colleagues have reported that $m i R-29 c$ is activated by the selective COX2 (cyclooxygenase-2) inhibitors, as Celecoxib, inducing apoptosis, which suggests that miR-29c restoring may be a possible treatment for GC [125]. In contrast, Wang et al. found that in GC this miRNA acts as a metastatic suppressors by directly targeting catenin- $\delta$ (CTNND1), a gene involved in cell to cell adhesion and signal transduction [126]. These discoveries suggest the differential roles for miR-29, not only acting as tumor suppressor miRNA in GC, but also serving as predictors for GC prevention. 
MYC can induce miR-9-3 expression that targets E-cadherin (CDH1), a cellular adhesion protein essential for the cell-cell contact of the gastric epithelium, and promoting tumor cell migration and invasion, leading to EMT in GC $[83,127]$. The MYC and N-MYC regulation of miR-9 seems to be one of the main pathways to metastasis $[128,129]$. In neuroblastoma patients, N-MYC amplification directly correlates with the miR-9 levels and metastatic spread [128]. On the contrary, let-7 has target genes [HMGA2 (High Mobility Group AT-Hook 2), IMP-1 (IGF2 mRNA-binding protein 1), LIN28B (Lin-28 homolog B), Ras, and MYC) important for cancer cell stemness [130]. Although let-7a expression was high in GC cell lines, it expression diminished progressively during the progression of gastric mucosa cancerization, confirming that the regulation of let-7a expression may be used as a novel biomarker and molecular mechanism of drug response to treatment [114]. Enhancer of zeste homolog 2 (EZH2) is a histone methyltransferase involved in the silencing of many genes related to cell proliferation and differentiation. EZH2 in turn enhances H3K27 trimethylation and DNA methylation in let-7 promoter, and, as a consequence, let-7 $a$ and let-7c expressions are downregulated, resulting in Ras-ERK pathway activation [77]. Additionally, a previous mentioned study showed that GKN1 inhibits EZH2 expression through miR-185 [118]. GKN1 is considered a tumor suppressor gene as it indirectly inhibits EZH2 and DNMT1, through miR-185 and directly inhibits the Histone deacetylase 1 (HDAC1). The 8q24.21 PVT1 oncogene also regulates EZH2 activity. PVT1 recruits EZH2 to occupy the genomic sites of P15/INK4b and $P 16 / I N K 4 b$ genes, silencing these gene expressions and enforcing GC cell proliferation [34,131]. The alteration of DNMT1 and HDAC1 expression can lead to demethylation and histone deacetylation, respectively, of several genes important for the maintenance of cell homeostasis, for example, $M Y C$, E-cadherin, CDKN1A, and CDKN2A [132-135].

Other miRNAs such as miR-135a, miR-186, miR-494, miR-200c, miR-374a/b, miR-101 and miR-548 are also targeted by MYC gene (Table 2). miR-101 is downregulated in GC cell lines, and when overexpressed decreases MYC mRNA and protein expression and decreases cell growth, colony formation, and the number of cells in S phase, while increases the number of cells in G1 phase [99]. Similarly, miR-25 affects the control of cell cycle. Zhang et al. reported miR-25 upregulation in AGS cells playing an antiapoptotic role as it inhibited FBXW7 and promoted oncogenes, such as MYC and cyclin E1 (CCNE1), required for G1/S transition [86]. Moreover, the expressions of CCNE1 and MYC are promoted by the upregulation of $m i R-25$, suggesting a possible regulatory mechanism of $m i R-25$ in AGS cells. As mentioned above, cagA enhances MYC expression, and MYC regulates EZH2 through miR-26 and $m i R-101$ downregulation (Figure 3) [92]. The H. pylori infection also suppresses MYC-induced miR-22 expression in the gastric mucosa, and is associated with an abnormal cell proliferation [91]. $m i R-22$ is characterized as a key regulator of the self-renewal machinery of the hematopoietic system. This miRNA acts as a proto-oncogenic miRNA via genome-wide deregulation of the epigenetic state through the inhibition of methylcytosine dioxygenase TET2 proteins [136]. On the contrary, miR-22 is suppressed by $H$. pylori infection, leading to uncontrolled gastric epithelial cell proliferation and overexpression of NLRP3 (NACHT, LRR and PYD domains-containing protein 3), a gene that helps the cell to recognize pathogen-associated molecular patterns [91]. These results indicate that the environment influences the modulation of miRNAs that consequently regulate important pathways of cell proliferation.

The polycistronic miRNA cluster miR-17-92 encodes six matures miRNAs (miR-17; miR-18a, miR-19a, miR-20a, miR-19b-1, and miR-92a-1), also known as oncomiR-1, and is overexpressed in GC [60]. A mice model that overexpresses the $m i R-17-92$ cluster developed spontaneous benign tumors in the intestinal tract [88]. Interestingly, MYC functions as a transcriptional factor to miR-17-92 gene, resulting in the upregulation of this cluster and contributing to MYC oncogenic proprieties $[60,90,137]$, and miR-17 overexpression is associated with MYC in GC tissues [88]. Another example of the importance of this cluster is miR-29, which is observed to be downregulated in GC, and its increased tissue expression is associated with higher overall survival rate [93]. $m i R-18 a, m i R-19 a$, and $m i R-19 b$ are also capable of inducing MYC expression. Ectopic expression of miR-18a is capable of retarding gastric tumor growth and angiogenesis through the inhibition of mTOR pathway and is inversely correlated with PIAS3 
expression, a STAT3 inhibitor, leading to STAT3p upregulation and induction of MYC expression, with a high predictive value for prognosis of patients with GC $[89,138,139]$. miR-19a and miR-19b are also upregulated in GC samples, and directly target MXD1 (MAX Dimerization Protein 1), an important molecule that competes with MYC for MAX (Myc-Associated factor X) binding, impairing the oncogenic MYC-MAX-MXD1 network [140]. Therefore, miR-19a/b are linked to MYC overexpression through MXD1 inhibition. However, the complete molecular mechanism underlying miR-17-92 cluster overexpression has not been clearly evaluated in GC [88]. The robust genetic circuitries for the maintenance of cellular dysfunction in GC generate a molecular complex relationship between MYC and miRNAs. This complex relationship implies the control of MYC oncogene pathways leading to tumor development and progression. The studies herein mentioned suggest that miRNAs can not only act directly in one of the main interactions pathways that control MYC expression in GC but also have potential roles as targets for new therapeutic strategies against GC.

Finally, several miRNAs modulate the multidrug resistance of GC, and understanding their role in MYC oncopathway and in the carcinogenesis can elucidate the mechanisms responsible for low survival rate of GC patients. Cao et al. showed that miR-1284 is downregulated in GC cells, and when it is reintroduced, it enhances the drug-induced apoptosis and impairs the migration and invasion of GC cells [113]. Another example is the down-regulation of miR-135b, which was capable of multidrug-resistant protein repression and cell proliferation and induction of cell apoptotic rate of GC cells [141]. Taken together, all the above studies indicate that understanding the complex relationship between MYC and miRNAs is extremely important for gastric carcinogenesis, prognosis and treatment response.

\subsection{MYC can Promote Angiogenesis through the Regulation of microRNAs}

Another interesting point is that miR-15a/16-1, miR-26a, miR-29, miR-34a, and miR-150 can suppress innumerous survival signaling pathways; however, they are repressed by MYC (Figure 3) $[60,84,85]$. Moreover, MYC can act as a vascular endothelial growth factor (VEGF) transcriptional factor since it upregulates the expression of proangiogenic factors, promoting angiogenesis and vasculogenesis [142]. Furthermore, in silico data showed that at least eight miRNAs that strictly regulate the VEGF translation are known (miR-15a, miR-16, miR-17, miR-20a, miR-34a, miR-93, miR-106a, miR-106b), all under MYC control [143]. The VEGF is one of the most important angiogenic growth factors, therefore these results highlight the importance of the deregulation of MYC's angiogenic properties in the microenvironment during tumors establishment and progression.

\section{Conclusions}

MYC and other 8q24.21 genes are associated with GC development and progression. We showed that miRNAs have an influence on the expression of MYC and vice versa. One of the major consequences of MYC activation is the extensive reprogramming of the expression pattern of miRNAs in tumor cells, which is closely linked to the modulation of critical pathways associated with cancer etiology, including MYC-MAX-MXD1 and Ras-ERK pathways. Therefore, the studies reviewed revealed that MYC and miRNAs have a very complex interaction in GC that can be affected by external factors, such as bacterial and virus infection. Despite being one of the best-known and studied oncogenes, there is a lack of understanding regarding the application of this information for therapeutic interventions against GC. This application should likely be studied in conjunction with miRNAs expression and action once they appear to be highly correlated. Thus, the investigation of the role of miRNAs helps in the elucidation of underlying mechanisms of gastric carcinogenesis and are potential biomarkers that monitor the alteration of critical genomic driver regions, targeting new treatment strategies against GC.

In fact, besides acting as tumor biomarkers, the miRNAs mentioned in this review may also be used as targets for cancer therapies. Furthermore, there are some examples of miRNA-based therapies currently on clinical trials. A quick search on clinicaltrials.org using the key words "miR" and "cancer" reveals that are 334 studies and many of them are active. For example, the biotechnology company 
miRagen has been developing therapies using miRNAs: MRG-110, MRG-106 and MRG-201. The first one, MRG-110, uses an LNA-modified antisense oligonucleotides to inhibit miR-92 and works by increasing the growth of new blood vessels to treat wound healing and heart failure. MRG-106 uses the same technology to silence miR-155 to treat T-cell lymphoma. MRG-201, in contrast, mimics miR-29 treat pathological fibrosis, such as keloids and scar tissue formation. Developed by Regulus Therapeutics, RGLS5579 and RG-012 are design to treat patients with glioblastoma multiforme (GBM) and Alport Syndrome, respectively. These drugs target miR-10b and miR-21 inhibiting their function. In addition, there are other less explored approaches, such as using CRISPRi (CRISPR interference) to silence the expression of upregulated miRNAs. In this strategy, a dead-Cas 9 fused with transcriptional repressors is targeted to the promoter region of a miRNA, preventing its expression [144,145]. Although there are therapies showing promising results, one of the main challenges in these approaches is to find efficient delivery methods [146]. In this context, a few options are currently been tested, for instance intratumoral injections [147], viral vectors [148], lipid vectors [149], and inorganic nanoparticles [150].

To our knowledge, there are no clinical trials using miRNAs as therapeutic targets for GC to date. Therefore, the characterization of these molecules will be useful in the development of new prognosis, diagnosis, and treatment strategies for patients with GC.

Author Contributions: A.C.A., M.F.L. and M.A.C.S. conceived the article; A.C.A., M.F.L., D.Q.C., B.T.R.K. and M.A.C.S. wrote the article. All authors gave intellectual input. All authors have read and agreed to the published version of the manuscript.

Funding: The authors' work was financed in part by the Coordenação de Aperfeiçoamento de Pessoal de Nível Superior (CAPES; MCS: No. 201567/2009-1; ACA, COG); the Conselho Nacional de Desenvolvimento Científico e Tecnológico (CNPq; MCS: No. 303871/2014-8; RRB; DQC); and the Fundação de Amparo à Pesquisa do Estado de São Paulo (FAPESP; MCS: No. 2016/25562-0, MFL: No. 2012/14768-5, FW: No. 2016/19953-6, B.T.R.K.: No. 2019/20592-6).

Conflicts of Interest: The authors declare that they have no conflict of interest.

\section{Abbreviations}

$\begin{array}{ll}\text { GC } & \text { Gastric cancer } \\ \text { miRNA } & \text { microRNA } \\ \text { RISC } & \text { RNA-induced silencing complex } \\ \text { H. pylori } & \text { Helicobacter pylori } \\ \text { IARC } & \text { International Agency for Research on Cancer } \\ \text { EMT } & \text { Epithelial-mesenchymal matrix } \\ \text { GBM } & \text { Glioblastoma multiforme } \\ \text { CRISPRi } & \text { CRISPR interference }\end{array}$

\section{References}

1. Ferro, A.; Peleteiro, B.; Malvezzi, M.; Bosetti, C.; Bertuccio, P.; Levi, F.; Negri, E.; La Vecchia, C.; Lunet, N. Worldwide trends in gastric cancer mortality (1980-2011), with predictions to 2015, and incidence by subtype. Eur. J. Cancer 2014, 50, 1330-1344. [CrossRef] [PubMed]

2. Jemal, A.; Bray, F.; Center, M.M.; Ferlay, J.; Ward, E.; Forman, D. Global cancer statistics. CA A Cancer J. Clin. 2011, 61, 69-90. [CrossRef] [PubMed]

3. Bray, F.; Ferlay, J.; Soerjomataram, I.; Siegel, R.L.; Torre, L.A.; Jemal, A. Global cancer statistics 2018: GLOBOCAN estimates of incidence and mortality worldwide for 36 cancers in 185 countries. CA A Cancer J. Clin. 2018, 68, 394-424. [CrossRef] [PubMed]

4. Carcas, L.P. Gastric cancer review. J. Carcinog. 2014, 13, 14. [CrossRef]

5. Group, H.A.C.C. Gastric cancer and Helicobacter pylori: A combined analysis of 12 case control studies nested within prospective cohorts. Gut 2001, 49, 347-353. [CrossRef] 
6. Hino, R.; Uozaki, H.; Murakami, N.; Ushiku, T.; Shinozaki, A.; Ishikawa, S.; Morikawa, T.; Nakaya, T.; Sakatani, T.; Takada, K.; et al. Activation of DNA Methyltransferase 1 by EBV Latent Membrane Protein 2A Leads to Promoter Hypermethylation of PTEN Gene in Gastric Carcinoma. Cancer Res. 2009, 69, 2766-2774. [CrossRef]

7. D'Elia, L.; Galletti, F.; Strazzullo, P. Dietary salt intake and risk of gastric cancer. Cancer Treat. Res. 2014, 159, 83-95. [CrossRef]

8. Woo, H.D.; Park, S.; Oh, K.; Kim, H.J.; Shin, H.R.; Moon, H.K.; Kim, J. Diet and cancer risk in the Korean population: A meta- analysis. Asian Pac. J. Cancer Prev. 2014, 15, 8509-8519. [CrossRef]

9. Duell, E.J.; Travier, N.; Lujan-Barroso, L.; Clavel-Chapelon, F.; Boutron-Ruault, M.C.; Morois, S.; Palli, D.; Krogh, V.; Panico, S.; Tumino, R.; et al. Alcohol consumption and gastric cancer risk in the European Prospective Investigation into Cancer and Nutrition (EPIC) cohort. Am. J. Clin. Nutr. 2011, 94, 1266-1275. [CrossRef]

10. Ladeiras-Lopes, R.; Pereira, A.K.; Nogueira, A.; Pinheiro-Torres, T.; Pinto, I.; Santos-Pereira, R.; Lunet, N. Smoking and gastric cancer: Systematic review and meta-analysis of cohort studies. Cancer Causes Control 2008, 19, 689-701. [CrossRef]

11. Takeno, S.S.; Leal, M.F.; Lisboa, L.C.; Lipay, M.V.; Khayat, A.S.; Assumpção, P.P.; Burbano, R.R.; Smith Mde, A. Genomic alterations in diffuse-type gastric cancer as shown by high-resolution comparative genomic hybridization. Cancer Genet. Cytogenet. 2009, 190. [CrossRef]

12. Fu, D.G. Epigenetic alterations in gastric cancer (Review). Mol. Med. Rep. 2015, 12, 3223-3230. [CrossRef] [PubMed]

13. Qu, Y.; Dang, S.; Hou, P. Gene methylation in gastric cancer. Clin. Chim. Acta 2013, 424, 53-65. [CrossRef] [PubMed]

14. Burbano, R.R.; Assumpcao, P.P.; Leal, M.F.; Calcagno, D.Q.; Guimaraes, A.C.; Khayat, A.S.; Takeno, S.S.; Chen, E.S.; De Arruda Cardoso Smith, M. C-MYC locus amplification as metastasis predictor in intestinal-type gastric adenocarcinomas: CGH study in Brazil. Anticancer Res. 2006, 26, 2909-2914.

15. Calcagno, D.Q.; Guimarães, A.C.; Leal, M.F.; Seabra, A.D.; Khayat, A.S.; Pontes, T.B.; Assumpção, P.P.; Smith, M.D.A.C.; Burbano, R.R. MYC Insertions in Diffuse-type Gastric Adenocarcinoma. Anticancer Res. 2009, 29, 2479-2483.

16. Calcagno, D.Q.; Leal, M.F.; Assumpção, P.P.; Smith, M.A.C.; Burbano, R. MYC and gastric adenocarcinoma carcinogenesis. World J. Gastroenterol. 2008, 14, 5962-5968. [CrossRef]

17. Calcagno, D.Q.; Leal, M.F.; Seabra, A.D.; Khayat, A.S.; Chen, E.S.; Demachki, S.; Assumpcao, P.P.; Faria, M.H.; Rabenhorst, S.H.; Ferreira, M.V.; et al. Interrelationship between chromosome 8 aneuploidy, C-MYC amplification and increased expression in individuals from northern Brazil with gastric adenocarcinoma. World J. Gastroenterol. 2006, 12, 6207-6211. [CrossRef]

18. Venkateswaran, N.; Conacci-Sorrell, M. MYC leads the way. Small Gtpases 2017, 11, 1-9. [CrossRef]

19. Stine, Z.E.; Walton, Z.E.; Altman, B.J.; Hsieh, A.L.; Dang, C.V. MYC, Metabolism, and Cancer. Cancer Discov. 2015, 5, 1024-1039. [CrossRef]

20. Lancho, O.; Herranz, D. The MYC Enhancer-ome: Long-Range Transcriptional Regulation of MYC in Cancer. Trends Cancer 2018, 4, 810-822. [CrossRef]

21. Calcagno, D.Q.; Freitas, V.M.; Leal, M.F.; de Souza, C.R.; Demachki, S.; Montenegro, R.; Assumpcao, P.P.; Khayat, A.S.; Smith, M.D.; Dos Santos, A.K.; et al. MYC, FBXW7 and TP53 copy number variation and expression in gastric cancer. BMC Gastroenterol. 2013, 13, 141. [CrossRef] [PubMed]

22. Calcagno, D.Q.; Leal, M.F.; Demachki, S.; Araujo, M.T.; Freitas, F.W.; Oliveira e Souza, D.; Assumpcao, P.P.; Ishak, G.; de Smith, M.; Burbano, R.R. MYC in gastric carcinoma and intestinal metaplasia of young adults. Cancer Genet. Cytogenet. 2010, 202, 63-66. [CrossRef] [PubMed]

23. Costa Raiol, L.C.; Figueira Silva, E.C.; Mendes da Fonseca, D.; Leal, M.F.; Guimarães, A.C.; Calcagno, D.Q.; Burbano, R.R. Interrelationship between MYC gene numerical aberrations and protein expression in individuals from northern Brazil with early gastric adenocarcinoma. Cancer Genet. Cytogenet. 2008, 181, 31-35. [CrossRef] [PubMed]

24. de Souza, C.R.; Leal, M.F.; Calcagno, D.Q.; Costa Sozinho, E.K.; Borges Bdo, N.; Montenegro, R.C.; Dos Santos, A.K.; Dos Santos, S.E.; Ribeiro, H.F.; Assumpcao, P.P.; et al. MYC deregulation in gastric cancer and its clinicopathological implications. PLoS ONE 2013, 8, e64420. [CrossRef] [PubMed] 
25. Leal, M.F.; Calcagno, D.Q.; Borges da Costa Jde, F.; Silva, T.C.; Khayat, A.S.; Chen, E.S.; Burbano, R.R. MYC, TP53, and chromosome 17 copy-number alterations in multiple gastric cancer cell lines and in their parental primary tumors. J. Biomed. Biotechnol. 2011, 2011, 631268. [CrossRef] [PubMed]

26. Borges da Costa, J.; Leal, M.F.; Silva, T.C.R.; Andrade Junior, E.F.; Rezende, A.P.; Carneiro Muniz Jé, A.P.; Burbano, R.R. Experimental Gastric Carcinogenesis in Cebus apella Nonhuman Primates. PLoS ONE 2011, 6, e21988. [CrossRef]

27. Silva, T.C.R.; Leal, M.F.; Calcagno, D.Q.; de Souza, C.R.T.; Khayat, A.S.; dos Santos, N.P.C.; Montenegro, R.C.; Rabenhorst, S.H.B.; Nascimento, M.Q.; Assumpção, P.P.; et al. hTERT, MYC and TP53 deregulation in gastric preneoplastic lesions. BMC Gastroenterol. 2012, 12, 85. [CrossRef]

28. Ribeiro, H.F.; Alcântara, D.F.A.; Matos, L.A.; Sousa, J.M.C.; Leal, M.F.; Smith, M.A.C.; Burbano, R.R.; Bahia, M.O. Cytogenetic characterization and evaluation of c-MYC gene amplification in PG100, a new Brazilian gastric cancer cell line. Braz. J. Med. Biol. Res. 2010, 43, 717-721. [CrossRef]

29. Calcagno, D.; Leal, M.; Takeno, S.; Assumpção, P.; Demachki, S.; Smith, M.; Burbano, R. Aneuploidy of Chromosome 8 and C-MYC Amplification in Individuals from Northern Brazil with Gastric Adenocarcinoma. Anticancer Res. 2005, 25, 4069-4074.

30. Colombo, T.; Farina, L.; Macino, G.; Paci, P. PVT1: A Rising Star among Oncogenic Long Noncoding RNAs. Biomed. Res. Int. 2015. [CrossRef]

31. Cui, M.; You, L.; Ren, X.; Zhao, W.; Liao, Q.; Zhao, Y. Long non-coding RNA PVT1 and cancer. Biochem. Biophys. Res. Commun. 2016, 471, 10-14. [CrossRef] [PubMed]

32. Kim, H.P.; Cho, G.A.; Han, S.W.; Shin, J.Y.; Jeong, E.G.; Song, S.H.; Lee, W.C.; Lee, K.H.; Bang, D.; Seo, J.S.; et al. Novel fusion transcripts in human gastric cancer revealed by transcriptome analysis. Oncogene 2013, 33, 5434. [CrossRef] [PubMed]

33. Derderian, C.; Orunmuyi, A.T.; Olapade-Olaopa, E.O.; Ogunwobi, O.O. PVT1 Signaling Is a Mediator of Cancer Progression. Front. Oncol. 2019, 9. [CrossRef] [PubMed]

34. Kong, R.; Zhang, E.; Yin, D.; You, L.; Xu, T.; Chen, W.; Xia, R.; Wan, L.; Sun, M.; Wang, Z.; et al. Long noncoding RNA PVT1 indicates a poor prognosis of gastric cancer and promotes cell proliferation through epigenetically regulating p15 and p16. Mol. Cancer 2015, 14. [CrossRef] [PubMed]

35. Huang, T.; Liu, H.W.; Chen, J.Q.; Wang, S.H.; Hao, L.Q.; Liu, M.; Wang, B. The long noncoding RNA PVT1 functions as a competing endogenous RNA by sponging miR-186 in gastric cancer. Biomed. Pharmacother. 2017, 88, 302-308. [CrossRef] [PubMed]

36. Dan-Dan, Z.; Xiu-fen, L.; Cheng-wei, L.; Prakash, P.O.; Xiao-dong, L. Long non-coding RNA PVT1: Emerging biomarker in digestive system cancer. Cell Prolif. 2017, 50, e12398. [CrossRef]

37. Zhang, L.; Kang, W.; Lu, X.; Ma, S.; Dong, L.; Zou, B. LncRNA CASC11 promoted gastric cancer cell proliferation, migration and invasion in vitro by regulating cell cycle pathway. Cell Cycle 2018, 17, 1886-1900. [CrossRef]

38. Fang, H.; Liu, H.-M.; Wu, W.-H.; Liu, H.; Pan, Y.; Li, W.-J. Upregulation of long noncoding RNA CCAT1-L promotes epithelial-mesenchymal transition in gastric adenocarcinoma. Onco Targets 2018, 11, 5647-5655. [CrossRef]

39. Li, N.; Jiang, K.; Fang, L.P.; Yao, L.L.; Yu, Z. Knockdown of long noncoding RNA CCAT1 inhibits cell growth, invasion and peritoneal metastasis via downregulation of Bmi-1 in gastric cancer. Neoplasma 2018, 65, 736-744. [CrossRef]

40. Wu, S.W.; Hao, Y.P.; Qiu, J.H.; Zhang, D.B.; Yu, C.G.; Li, W.H. High expression of long non-coding RNA CCAT2 indicates poor prognosis of gastric cancer and promotes cell proliferation and invasion. Minerva Med. 2017, 108, 317-323. [CrossRef]

41. Hayashi, H.; Arao, T.; Togashi, Y.; Kato, H.; Fujita, Y.; De Velasco, M.A.; Kimura, H.; Matsumoto, K.; Tanaka, K.; Okamoto, I.; et al. The OCT4 pseudogene POU5F1B is amplified and promotes an aggressive phenotype in gastric cancer. Oncogene 2013, 34, 199-208. [CrossRef] [PubMed]

42. Yu, Z.Y.; Wang, Z.; Lee, K.Y.; Yuan, P.; Ding, J. Effect of silencing colon cancer-associated transcript 2 on the proliferation, apoptosis and autophagy of gastric cancer BGC-823 cells. Oncol. Lett. 2018, 15, 3127-3132. [CrossRef] [PubMed]

43. Park, K.U.; Lee, H.E.; Park do, J.; Jung, E.J.; Song, J.; Kim, H.H.; Choe, G.; Kim, W.H.; Lee, H.S. MYC quantitation in cell-free plasma DNA by real-time PCR for gastric cancer diagnosis. Clin. Chem. Lab. Med. 2009, 47, 530-536. [CrossRef] [PubMed] 
44. Takahashi, Y.; Shintaku, K.; Ishii, Y.; Asai, S.; Ishikawa, K.; Fujii, M. Analysis of MYC and chromosome 8 copy number changes in gastrointestinal cancers by dual-color fluorescence in situ hybridization. Cancer Genet. Cytogenet. 1998, 107, 61-64. [CrossRef]

45. Ishak, G.; Leal, M.F.; dos Santos, N.P.C.; Demachki, S.; Nunes, C.A.M.; do Nascimento Borges, B.; Calcagno, D.Q.; Smith, M.C.; Assumpção, P.P.; Burbano, R.R. Deregulation of MYC and TP53 through genetic and epigenetic alterations in gallbladder carcinomas. Clin. Exp. Med. 2015, 15, 421-426. [CrossRef] [PubMed]

46. Ma, G.; Gu, D.; Lv, C.; Chu, H.; Xu, Z.; Tong, N.; Wang, M.; Tang, C.; Xu, Y.; Zhang, Z.; et al. Genetic variant in 8q24 is associated with prognosis for gastric cancer in a Chinese population. J. Gastroenterol. Hepatol. 2015, 30, 689-695. [CrossRef] [PubMed]

47. Anauate, A.C.; Leal, M.F.; Wisnieski, F.; Santos, L.C.; Gigek, C.O.; Chen, E.S.; Calcagno, D.Q.; Assumpção, P.P.; Demachki, S.; Arasaki, C.H.; et al. Analysis of 8q24.21 miRNA cluster expression and copy number variation in gastric cancer. Future Med. Chem. 2019, 11, 947-958. [CrossRef]

48. Li, L.; Jia, F.; Bai, P.; Liang, Y.; Sun, R.; Yuan, F.; Zhang, L.; Gao, L. Association between polymorphisms in long non-coding RNA PRNCR1 in 8q24 and risk of gastric cancer. Tumor Biol. 2016, 37, 299-303. [CrossRef]

49. Li, T.; Meng, X.L.; Yang, W.Q. Long Noncoding RNA PVT1 Acts as a "Sponge" to Inhibit microRNA-152 in Gastric Cancer Cells. Dig. Dis. Sci. 2017, 62, 3021-3028. [CrossRef]

50. Ha, M.; Kim, V.N. Regulation of microRNA biogenesis. Nat. Rev. Mol. Cell Biol. 2014, 15, 509-524. [CrossRef]

51. Piletič, K.; Kunej, T. MicroRNA epigenetic signatures in human disease. Arch. Toxicol. 2016, 90, $2405-2419$. [CrossRef] [PubMed]

52. Zhang, M.; Du, X. Noncoding RNAs in gastric cancer: Research progress and prospects. World J. Gastroenterol. 2016, 22, 6610-6618. [CrossRef] [PubMed]

53. Yan, L.H.; Chen, Z.N.; Li, L.; Chen, J.; Wei, W.E.; Mo, X.W.; Qin, Y.Z.; Lin, Y.; Chen, J.S. miR-135a promotes gastric cancer progression and resistance to oxaliplatin. Oncotarget 2016, 7, 70699-70714. [CrossRef]

54. Venturutti, L.; Cordo Russo, R.I.; Rivas, M.A.; Mercogliano, M.F.; Izzo, F.; Oakley, R.H.; Pereyra, M.G.; De Martino, M.; Proietti, C.J.; Yankilevich, P.; et al. MiR-16 mediates trastuzumab and lapatinib response in ErbB-2-positive breast and gastric cancer via its novel targets CCNJ and FUBP1. Oncogene 2016, 35, 6189-6202. [CrossRef] [PubMed]

55. Zhang, J.; Zhou, Y.; Huang, T.; Wu, F.; Pan, Y.; Dong, Y.; Wang, Y.; Chan, A.K.Y.; Liu, L.; Kwan, J.S.H.; et al. FGF18, a prominent player in FGF signaling, promotes gastric tumorigenesis through autocrine manner and is negatively regulated by miR-590-5p. Oncogene 2019, 38, 33-46. [CrossRef]

56. Chen, S.; Wu, J.; Jiao, K.; Wu, Q.; Ma, J.; Chen, D.; Kang, J.; Zhao, G.; Shi, Y.; Fan, D.; et al. MicroRNA-495-3p inhibits multidrug resistance by modulating autophagy through GRP78/mTOR axis in gastric cancer. Cell Death Dis. 2018, 9, 1070. [CrossRef]

57. Lu, J.; Getz, G.; Miska, E.A.; Alvarez-Saavedra, E.; Lamb, J.; Peck, D.; Sweet-Cordero, A.; Ebert, B.L.; Mak, R.H.; Ferrando, A.A.; et al. MicroRNA expression profiles classify human cancers. Nature 2005, 435, 834-838. [CrossRef]

58. Swier, L.; Dzikiewicz-Krawczyk, A.; Winkle, M.; van den Berg, A.; Kluiver, J. Intricate crosstalk between MYC and non-coding RNAs regulates hallmarks of cancer. Mol. Oncol. 2019, 13, 26-45. [CrossRef]

59. Mukherjee, B.; Morgenbesser, S.D.; DePinho, R.A. Myc family oncoproteins function through a common pathway to transform normal cells in culture: Cross-interference by Max and trans-acting dominant mutants. Genes Dev. 1992, 6, 1480-1492. [CrossRef]

60. Tao, J.; Zhao, X.; Tao, J. c-MYC-miRNA circuitry. Cell Cycle 2014, 13, 191-198. [CrossRef]

61. Chen, Z.; Soutto, M.; Rahman, B.; Fazili, M.W.; Peng, D.; Blanca Piazuelo, M.; Chen, H.; Kay Washington, M.; Shyr, Y.; El-Rifai, W. Integrated expression analysis identifies transcription networks in mouse and human gastric neoplasia. Genes Chromosomes Cancer 2017, 56, 535-547. [CrossRef]

62. Kim, H.K.; Choi, I.J.; Kim, C.G.; Kim, H.S.; Oshima, A.; Yamada, Y.; Arao, T.; Nishio, K.; Michalowski, A.; Green, J.E. Three-gene predictor of clinical outcome for gastric cancer patients treated with chemotherapy. Pharm. J. 2012, 12, 119-127. [CrossRef]

63. Wisnieski, F.; Calcagno, D.Q.; Leal, M.F.; Chen, E.S.; Gigek, C.O.; Santos, L.C.; Pontes, T.B.; Rasmussen, L.T.; Payão, S.L.M.; Assumpção, P.P.; et al. Differential expression of histone deacetylase and acetyltransferase genes in gastric cancer and their modulation by trichostatin A. Tumor Biol. 2014, 35, 6373-6381. [CrossRef]

64. Dang, C.V. MYC on the path to cancer. Cell 2012, 149, 22-35. [CrossRef] 
65. Lin, C.Y.; Loven, J.; Rahl, P.B.; Paranal, R.M.; Burge, C.B.; Bradner, J.E.; Lee, T.I.; Young, R.A. Transcriptional amplification in tumor cells with elevated c-Myc. Cell 2012, 151, 56-67. [CrossRef] [PubMed]

66. Dang, C.V.; O’Donnell, K.A.; Zeller, K.I.; Nguyen, T.; Osthus, R.C.; Li, F. The c-Myc target gene network. Semin. Cancer Biol. 2006, 16. [CrossRef] [PubMed]

67. Dang, C.V. c-Myc target genes involved in cell growth, apoptosis, and metabolism. Mol. Cell. Biol. 1999, 19, 1-11. [CrossRef] [PubMed]

68. Lee, G.Y.; Chun, Y.S.; Shin, H.W.; Park, J.W. Potential role of the N-MYC downstream-regulated gene family in reprogramming cancer metabolism under hypoxia. Oncotarget 2016, 7, 57442-57451. [CrossRef] [PubMed]

69. Lima, V.P.; de Lima, M.A.; Andre, A.R.; Ferreira, M.V.; Barros, M.A.; Rabenhorst, S.H. H pylori (CagA) and Epstein-Barr virus infection in gastric carcinomas: Correlation with p53 mutation and c-Myc, Bcl-2 and Bax expression. World J. Gastroenterol. 2008, 14, 884-891. [CrossRef] [PubMed]

70. Bueno, M.J.; Gómez de Cedrón, M.; Gómez-López, G.; Pérez de Castro, I.; Di Lisio, L.; Montes-Moreno, S.; Martínez, N.; Guerrero, M.; Sánchez-Martínez, R.; Santos, J.; et al. Combinatorial effects of microRNAs to suppress the Myc oncogenic pathway. Blood 2011, 117, 6255-6266. [CrossRef]

71. Alzahrani, S.; Lina, T.T.; Gonzalez, J.; Pinchuk, I.V.; Beswick, E.J.; Reyes, V.E. Effect of Helicobacter pylori on gastric epithelial cells. World J. Gastroenterol. 2014, 20, 12767-12780. [CrossRef] [PubMed]

72. Ott, G.; Rosenwald, A.; Campo, E. Understanding MYC-driven aggressive B-cell lymphomas: Pathogenesis and classification. Blood 2013, 122, 3884-3891. [CrossRef] [PubMed]

73. De Martel, C.; Ferlay, J.; Franceschi, S.; Vignat, J.; Bray, F.; Forman, D.; Plummer, M. Global burden of cancers attributable to infections in 2008: A review and synthetic analysis. Lancet Oncol. 2012, 13, 607-615. [CrossRef]

74. IARC. Helicobacter pylori Eradication as a Strategy for Preventing Gastric Cancer. Helicobacter pylori Working Group. International Agency for Research on Cancer. IARC Work. Group Rep. 2014, 8.

75. Correa, P. New strategies for the prevention of gastric cancer: Helicobacter pylori and genetic susceptibility. J. Surg. Oncol. 2005, 90, 134-138. [CrossRef]

76. Keates, S.; Keates, A.C.; Warny, M.; Peek, R.M.; Murray, P.G.; Kelly, C.P. Differential Activation of Mitogen-Activated Protein Kinases in AGS Gastric Epithelial Cells by cag+ and cag- Helicobacter pylori. J. Immunol. 1999, 163, 5552-5559.

77. Hayashi, Y.; Tsujii, M.; Wang, J.; Kondo, J.; Akasaka, T.; Jin, Y.; Li, W.; Nakamura, T.; Nishida, T.; Iijima, H.; et al. CagA mediates epigenetic regulation to attenuate let-7 expression in Helicobacter pylori-related carcinogenesis. Gut 2013, 62, 1536-1546. [CrossRef]

78. Silva-Fernandes, I.d.J.L.; Alves, M.K.S.; Lima, V.P.; de Lima, M.A.P.; Barros, M.A.P.; Ferreira, M.V.P.; Rabenhorst, S.H.B. Differential expression of MYC in H. pylori-related intestinal and diffuse gastric tumors. Virchows Arch. 2011, 458, 725-731. [CrossRef]

79. Nardone, G.; Staibano, S.; Rocco, A.; Mezza, E.; D'Armiento, F.; Insabato, L.; Coppola, A.; Salvatore, G.; Lucariello, A.; Figura, N.; et al. Effect of Helicobacter pylori infection and its eradication on cell proliferation, DNA status, and oncogene expression in patients with chronic gastritis. Gut 1999, 44, 789-799. [CrossRef]

80. Byun, E.; Park, B.; Lim, J.W.; Kim, H. Activation of NF-kB and AP-1 Mediates Hyperproliferation by Inducing $\beta$-Catenin and c-Myc in Helicobacter pylori-Infected Gastric Epithelial Cells. Yonsei Med. J. 2016, 57, 647-651. [CrossRef]

81. Niwa, T.; Tsukamoto, T.; Toyoda, T.; Mori, A.; Tanaka, H.; Maekita, T.; Ichinose, M.; Tatematsu, M.; Ushijima, T. Inflammatory Processes Triggered by Helicobacter pylori Infection Cause Aberrant DNA Methylation in Gastric Epithelial Cells. Cancer Res. 2010, 70, 1430-1440. [CrossRef] [PubMed]

82. Zhang, X.; Qian, Y.; Li, F.; Bei, S.; Li, M.; Feng, L. microRNA-9 selectively targets LMX1A to promote gastric cancer cell progression. Biochem. Biophys. Res. Commun. 2018, 505, 405-412. [CrossRef] [PubMed]

83. Oliveira, K.C.D.S.; Bona, A.B.; Da Silva, F.J.; Pinheiro, T.M.; Alcantara, D.D.F.A.; Lamarao, L.M.; Moreira-Nunes, C.A.; Assumpção, P.P.; Burbano, R.R.; Calcagno, D.Q. Expression of hsa-miR-9 and MYC Copy Number Variation in Hereditary Diffuse Gastric Cancer. Anticancer Res. 2017, 37, 2401-2406. [CrossRef] [PubMed]

84. Zhang, X.; Chen, X.; Lin, J.; Lwin, T.; Wright, G.; Moscinski, L.C.; Dalton, W.S.; Seto, E.; Wright, K.; Sotomayor, E.; et al. Myc represses miR-15a/miR-16-1 expression through recruitment of HDAC3 in mantle cell and other non-Hodgkin B-cell lymphomas. Oncogene 2012, 31, 3002-3008. [CrossRef] [PubMed] 
85. Kang, W.; Tong, J.H.M.; Lung, R.W.M.; Dong, Y.; Zhao, J.; Liang, Q.; Zhang, L.; Pan, Y.; Yang, W.; Pang, J.C.S.; et al. Targeting of YAP1 by microRNA-15a and microRNA-16-1 exerts tumor suppressor function in gastric adenocarcinoma. Mol. Cancer 2015, 14, 52. [CrossRef]

86. Zhang, Y.; Peng, Z.; Zhao, Y.; Chen, L. microRNA-25 Inhibits Cell Apoptosis of Human Gastric Adenocarcinoma Cell Line AGS via Regulating CCNE1 and MYC. Med. Sci. Monit. Int. Med. J. Exp. Clin. Res. 2016, 22, 1415-1420. [CrossRef]

87. Kim, Y.K.; Yu, J.; Han, T.S.; Park, S.Y.; Namkoong, B.; Kim, D.H.; Hur, K.; Yoo, M.W.; Lee, H.J.; Yang, H.K.; et al. Functional links between clustered microRNAs: Suppression of cell-cycle inhibitors by microRNA clusters in gastric cancer. Nucleic Acids Res. 2009, 37, 1672-1681. [CrossRef]

88. Park, D.; Lee, S.C.; Park, J.W.; Cho, S.Y.; Kim, H.K. Overexpression of miR-17 in gastric cancer is correlated with proliferation-associated oncogene amplification. Pathol. Int. 2014, 64, 309-314. [CrossRef]

89. Wu, W.; Takanashi, M.; Borjigin, N.; Ohno, S.; Fujita, K.; Hoshino, S.; Osaka, Y.; Tsuchida, A.; Kuroda, M. MicroRNA-18a modulates STAT3 activity through negative regulation of PIAS3 during gastric adenocarcinogenesis. Br. J. Cancer 2013, 108, 653-661. [CrossRef]

90. Mogilyansky, E.; Rigoutsos, I. The miR-17/92 cluster: A comprehensive update on its genomics, genetics, functions and increasingly important and numerous roles in health and disease. Cell Death Differ. 2013, 20, 1603-1614. [CrossRef]

91. Li, S.; Liang, X.; Ma, L.; Shen, L.; Li, T.; Zheng, L.; Sun, A.; Shang, W.; Chen, C.; Zhao, W.; et al. MiR-22 sustains NLRP3 expression and attenuates H. pylori-induced gastric carcinogenesis. Oncogene 2017, $37,884$. [CrossRef]

92. Deng, M.; Zhang, R.; He, Z.; Qiu, Q.; Lu, X.; Yin, J.; Liu, H.; Jia, X.; He, Z. TET-Mediated Sequestration of miR-26 Drives EZH2 Expression and Gastric Carcinogenesis. Cancer Res. 2017, 77, 6069-6082. [CrossRef] [PubMed]

93. Wang, D.; Fan, Z.; Liu, F.; Zuo, J. Hsa-miR-21 and Hsa-miR-29 in Tissue as Potential Diagnostic and Prognostic Biomarkers for Gastric Cancer. Cell. Physiol. Biochem. 2015, 37, 1454-1462. [CrossRef] [PubMed]

94. O'Donnell, K.A.; Wentzel, E.A.; Zeller, K.I.; Dang, C.V.; Mendell, J.T. c-Myc-regulated microRNAs modulate E2F1 expression. Nature 2005, 435, 839. [CrossRef] [PubMed]

95. Jafari, N.; Abediankenari, S. MicroRNA-34 dysregulation in gastric cancer and gastric cancer stem cell. Tumor Biol. 2017, 39. [CrossRef] [PubMed]

96. Christoffersen, N.R.; Shalgi, R.; Frankel, L.B.; Leucci, E.; Lees, M.; Klausen, M.; Pilpel, Y.; Nielsen, F.C.; Oren, M.; Lund, A.H. p53-independent upregulation of miR-34a during oncogene-induced senescence represses MYC. Cell Death Differ. 2009, 17, 236. [CrossRef] [PubMed]

97. Shin, V.Y.; Siu, M.T.; Liu, X.; Ng, E.K.O.; Kwong, A.; Chu, K.M. MiR-92 suppresses proliferation and induces apoptosis by targeting EP4/Notch1 axis in gastric cancer. Oncotarget 2018, 9, 24209-24220. [CrossRef]

98. Gao, P.; Tchernyshyov, I.; Chang, T.C.; Lee, Y.S.; Kita, K.; Ochi, T.; Zeller, K.I.; De Marzo, A.M.; Van Eyk, J.E.; Mendell, J.T.; et al. c-Myc suppression of miR-23a/b enhances mitochondrial glutaminase expression and glutamine metabolism. Nature 2009, 458, 762-765. [CrossRef]

99. Zhou, X.; Xia, Y.; Li, L.; Zhang, G. MiR-101 inhibits cell growth and tumorigenesis of Helicobacter pylori related gastric cancer by repression of SOCS2. Cancer Biol. 2015, 16, 160-169. [CrossRef]

100. Hou, X.; Zhang, M.; Qiao, H. Diagnostic significance of miR-106a in gastric cancer. Int. J. Clin. Exp. Pathol. 2015, 8, 13096-13101.

101. He, L.; Thomson, J.M.; Hemann, M.T.; Hernando-Monge, E.; Mu, D.; Goodson, S.; Powers, S.; Cordon-Cardo, C.; Lowe, S.W.; Hannon, G.J.; et al. A microRNA polycistron as a potential human oncogene. Nature 2005, 435, 828-833. [CrossRef]

102. You, W.; Zhang, X.; Ji, M.; Yu, Y.; Chen, C.; Xiong, Y.; Liu, Y.; Sun, Y.; Tan, C.; Zhang, H.; et al. MiR-152-5p as a microRNA passenger strand special functions in human gastric cancer cells. Int. J. Biol. Sci. 2018, 14, 644-653. [CrossRef] [PubMed]

103. Tan, B.; Li, Y.; Zhao, Q.; Fan, L.; Wang, D. ZNF139 increases multidrug resistance in gastric cancer cells by inhibiting miR-185. Biosci. Rep. 2018, 38, BSR20181023. [CrossRef] [PubMed]

104. Cao, C.; Sun, D.; Zhang, L.; Song, L. miR-186 affects the proliferation, invasion and migration of human gastric cancer by inhibition of Twist1. Oncotarget 2016, 7, 79956-79963. [CrossRef] [PubMed] 
105. Li, Y.; Nie, Y.; Tu, S.; Wang, H.; Zhou, Y.; Du, Y.; Cao, J.; Ye, M. Epigenetically deregulated miR-200c is involved in a negative feedback loop with DNMT3a in gastric cancer cells. Oncol. Rep. 2016, 36, 2108-2116. [CrossRef] [PubMed]

106. Hsu, K.W.; Wang, A.M.; Ping, Y.H.; Huang, K.H.; Huang, T.T.; Lee, H.C.; Lo, S.S.; Chi, C.W.; Yeh, T.S. Downregulation of tumor suppressor MBP-1 by microRNA-363 in gastric carcinogenesis. Carcinogenesis 2014, 35, 208-217. [CrossRef] [PubMed]

107. Ji, R.; Zhang, X.; Qian, H.; Gu, H.; Sun, Z.; Mao, F.; Yan, Y.; Chen, J.; Liang, Z.; Xu, W. miR-374 mediates the malignant transformation of gastric cancer-associated mesenchymal stem cells in an experimental rat model. Oncol. Rep. 2017, 38, 1473-1481. [CrossRef]

108. Sun, T.; Wang, C.; Xing, J.; Wu, D. miR-429 Modulates the expression of c-myc in human gastric carcinoma cells. Eur. J. Cancer 2011, 47, 2552-2559. [CrossRef]

109. He, W.; Li, Y.; Chen, X.; Lu, L.; Tang, B.; Wang, Z.; Pan, Y.; Cai, S.; He, Y.; Ke, Z. miR-494 acts as an anti-oncogene in gastric carcinoma by targeting c-myc. J. Gastroenterol. Hepatol. 2014, 29, 1427-1434. [CrossRef]

110. Li, R.; Yuan, W.; Mei, W.; Yang, K.; Chen, Z. MicroRNA 520d-3p inhibits gastric cancer cell proliferation, migration, and invasion by downregulating EphA2 expression. Mol. Cell. Biochem. 2014, 396, 295-305. [CrossRef]

111. Qian, K.; Mao, B.; Zhang, W.; Chen, H. MicroRNA-561 inhibits gastric cancercell proliferation and invasion by downregulating c-Myc expression. Am. J. Transl. Res. 2016, 8, 3802-3811. [PubMed]

112. Yang, M.; Cui, G.; Ding, M.; Yang, W.; Liu, Y.; Dai, D.; Chen, L. miR-935 promotes gastric cancer cell proliferation by targeting SOX7. Biomed. Pharmacother. 2016, 79, 153-158. [CrossRef] [PubMed]

113. Cao, W.; Wei, W.; Zhan, Z.; Xie, Y.; Xiao, Q. MiR-1284 modulates multidrug resistance of gastric cancer cells by targeting EIF4A1. Oncol. Rep. 2016, 35, 2583-2591. [CrossRef] [PubMed]

114. Deng, H.X.; Yu, Y.Y.; Zhou, A.Q.; Zhu, J.L.; Luo, L.N.; Chen, W.Q.; Hu, L.; Chen, G.X. Yangzheng Sanjie decoction regulates proliferation and apoptosis of gastric cancer cells by enhancing let-7a expression. World J. Gastroenterol. 2017, 23, 5538-5548. [CrossRef] [PubMed]

115. Xu, L.; Wang, F.; Xu, X.F.; Mo, W.H.; Xia, Y.J.; Wan, R.; Wang, X.P.; Guo, C.Y. Down-regulation of miR-212 expression by DNA hypermethylation in human gastric cancer cells. Med. Oncol. 2011, 28, 189-196. [CrossRef] [PubMed]

116. Yin, H.; Song, P.; Su, R.; Yang, G.; Dong, L.; Luo, M.; Wang, B.; Gong, B.; Liu, C.; Song, W.; et al. DNA Methylation mediated down-regulating of MicroRNA-33b and its role in gastric cancer. Sci. Rep. 2016, 6. [CrossRef]

117. Hong, X.; Xu, Y.; Qiu, X.; Zhu, Y.; Feng, X.; Ding, Z.; Zhang, S.; Zhong, L.; Zhuang, Y.; Su, C.; et al. MiR-448 promotes glycolytic metabolism of gastric cancer by downregulating KDM2B. Oncotarget 2016, 7, 22092-22102. [CrossRef]

118. Yoon, J.H.; Choi, Y.J.; Choi, W.S.; Ashktorab, H.; Smoot, D.T.; Nam, S.W.; Lee, J.Y.; Park, W.S. GKN1-miR-185-DNMT1 Axis Suppresses Gastric Carcinogenesis through Regulation of Epigenetic Alteration and Cell Cycle. Clin. Cancer Res. 2013, 19, 4599-4610. [CrossRef]

119. Huang, J.; Xiao, D.; Li, G.; Ma, J.; Chen, P.; Yuan, W.; Hou, F.; Ge, J.; Zhong, M.; Tang, Y.; et al. EphA2 promotes epithelial-mesenchymal transition through the $\mathrm{Wnt} /[$ beta]-catenin pathway in gastric cancer cells. Oncogene 2014, 33, 2737-2747. [CrossRef]

120. Zhang, X.; Zhao, X.; Fiskus, W.; Lin, J.; Lwin, T.; Rao, R.; Zhang, Y.; Chan, J.C.; Fu, K.; Marquez, V.E.; et al. Coordinated silencing of MYC-mediated miR-29 by HDAC3 and EZH2 as a therapeutic target of histone modification in aggressive B-Cell lymphomas. Cancer Cell 2012, 22, 506-523. [CrossRef]

121. Zhao, Z.; Wang, L.; Song, W.; Cui, H.; Chen, G.; Qiao, F.; Hu, J.; Zhou, R.; Fan, H. Reduced miR-29a-3p expression is linked to the cell proliferation and cell migration in gastric cancer. World J. Surg. Oncol. 2015, 13, 101. [CrossRef] [PubMed]

122. Liu, C.; Wang, F.; Zhao, H.; Gong, J.; Zhang, J.; Dong, L.; Luo, M.; Song, W.; Yu, J.; Li, J.; et al. Characterization of microRNA-29 family expression and investigation of their mechanistic roles in gastric cancer. Carcinogenesis 2013, 35, 497-506. [CrossRef]

123. Kawano, M.; Tanaka, K.; Itonaga, I.; Iwasaki, T.; Tsumura, H. c-Myc Represses Tumor-Suppressive microRNAs, let-7a, miR-16 and miR-29b, and Induces Cyclin D2-Mediated Cell Proliferation in Ewing's Sarcoma Cell Line. PLoS ONE 2015, 10, e0138560. [CrossRef] [PubMed] 
124. Yan, B.; Guo, Q.; Fu, F.J.; Wang, Z.; Yin, Z.; Wei, Y.B.; Yang, J.R. The role of miR-29b in cancer: Regulation, function, and signaling. Onco Targets 2015, 8, 539-548. [CrossRef]

125. Saito, Y.; Suzuki, H.; Imaeda, H.; Matsuzaki, J.; Hirata, K.; Tsugawa, H.; Hibino, S.; Kanai, Y.; Saito, H.; Hibi, T. The tumor suppressor microRNA-29c is downregulated and restored by celecoxib in human gastric cancer cells. Int. J. Cancer 2013, 132, 1751-1760. [CrossRef]

126. Wang, Y.; Liu, C.; Luo, M.; Zhang, Z.; Gong, J.; Li, J.; You, L.; Dong, L.; Su, R.; Lin, H.; et al. Chemotherapy-Induced miRNA-29c/Catenin- $\delta$ Signaling Suppresses Metastasis in Gastric Cancer. Cancer Res. 2015, 75, 1332-1344. [CrossRef]

127. Liu, M.; Zhu, H.; Yang, S.; Wang, Z.; Bai, J.; Xu, N. c-Myc suppressed E-cadherin through miR-9 at the post-transcriptional level. Cell Biol. Int. 2013, 37, 197-202. [CrossRef]

128. Ma, L.; Young, J.; Prabhala, H.; Pan, E.; Mestdagh, P.; Muth, D.; Teruya-Feldstein, J.; Reinhardt, F.; Onder, T.T.; Valastyan, S.; et al. miR-9, a MYC/MYCN-activated microRNA, regulates E-cadherin and cancer metastasis. Nat. Cell Biol. 2010, 12, 247-256. [CrossRef]

129. Sun, Y.; Wu, J.; Wu, S.H.; Thakur, A.; Bollig, A.; Huang, Y.; Liao, D.J. Expression profile of microRNAs in c-Myc induced mouse mammary tumors. Breast Cancer Res. Treat. 2009, 118, 185-196. [CrossRef]

130. Peter, M.E. Let-7 and miR-200 microRNAs: Guardians against pluripotency and cancer progression. Cell Cycle 2009, 8, 843-852. [CrossRef]

131. Li, T.; Mo, X.; Fu, L.; Xiao, B.; Guo, J. Molecular mechanisms of long noncoding RNAs on gastric cancer. Oncotarget 2016, 7, 8601-8612. [CrossRef] [PubMed]

132. Lima, E.M.; Leal, M.F.; Burbano, R.R.; Khayat, A.S.; Assumpção, P.P.; Bello, M.J.; Rey, J.A.; Smith, M.A.C.; Casartelli, C. Methylation status of ANAPC1, CDKN2A and TP53 promoter genes in individuals with gastric cancer. Braz. J. Med. Biol. Res. 2008, 41, 539-543. [CrossRef] [PubMed]

133. Wisnieski, F.; Calcagno, D.Q.; Leal, M.F.; Santos, L.C.; Gigek, C.O.; Chen, E.S.; Demachki, S.; Artigiani, R.; Assumpção, P.P.; Lourenço, L.G.; et al. CDKN1A histone acetylation and gene expression relationship in gastric adenocarcinomas. Clin. Exp. Med. 2017, 17, 121-129. [CrossRef] [PubMed]

134. Chan, A.O.; Lam, S.; Wong, B.C.; Wong, W.; Yuen, M.; Yeung, Y.; Hui, W.; Rashid, A.; Kwong, Y. Promoter methylation of E-cadherin gene in gastric mucosa associated with Helicobacter pylori infection and in gastric cancer. Gut 2003, 52, 502-506. [CrossRef]

135. Choi, W.S.; Seo, H.S.; Song, K.Y.; Yoon, J.H.; Kim, O.; Nam, S.W.; Lee, J.Y.; Park, W.S. Gastrokine 1 Expression in the Human Gastric Mucosa Is Closely Associated with the Degree of Gastritis and DNA Methylation. J. Gastric Cancer 2013, 13, 232-241. [CrossRef] [PubMed]

136. Song, S.J.; Ito, K.; Ala, U.; Kats, L.; Webster, K.; Sun, S.M.; Jongen-Lavrencic, M.; Manova-Todorova, K.; Teruya-Feldstein, J.; Avigan, D.E.; et al. The oncogenic microRNA miR-22 targets the TET2 tumor suppressor to promote hematopoietic stem cell self-renewal and transformation. Cell Stem Cell 2013, 13, 87-101. [CrossRef] [PubMed]

137. Kim, K.; Chadalapaka, G.; Lee, S.O.; Yamada, D.; Sastre-Garau, X.; Defossez, P.A.; Park, Y.Y.; Lee, J.S.; Safe, S. Identification of oncogenic microRNA-17-92/ZBTB4/specificity protein axis in breast cancer. Oncogene 2012, 31, 1034-1044. [CrossRef]

138. Zheng, Y.; Li, S.; Ding, Y.; Wang, Q.; Luo, H.; Shi, Q.; Hao, Z.; Xiao, G.; Tong, S. The role of miR-18a in gastric cancer angiogenesis. Hepatogastroenterology 2013, 60, 1809-1813.

139. Chen, Y.J.; Wu, H.; Zhu, J.M.; Li, X.D.; Luo, S.W.; Dong, L.; Liu, T.T.; Shen, X.Z. MicroRNA-18a modulates P53 expression by targeting IRF2 in gastric cancer patients. J. Gastroenterol. Hepatol. 2016, 31, 155-163. [CrossRef]

140. Wu, Q.; Yang, Z.; An, Y.; Hu, H.; Yin, J.; Zhang, P.; Nie, Y.; Wu, K.; Shi, Y.; Fan, D. MiR-19a/b modulate the metastasis of gastric cancer cells by targeting the tumour suppressor MXD1. Cell Death Dis. 2014, 5, e1144. [CrossRef]

141. Zhou, J.; Chen, Q. Poor expression of microRNA-135b results in the inhibition of cisplatin resistance and proliferation and induces the apoptosis of gastric cancer cells through MST1-mediated MAPK signaling pathway. FASEB J. 2019, 33, 3420-3436. [CrossRef] [PubMed]

142. Knies-Bamforth, U.E.; Fox, S.B.; Poulsom, R.; Evan, G.I.; Harris, A.L. c-Myc Interacts with Hypoxia to Induce Angiogenesis In vivo by a Vascular Endothelial Growth Factor-Dependent Mechanism. Cancer Res. 2004, 64, 6563-6570. [CrossRef]

143. El Baroudi, M.; Corà, D.; Bosia, C.; Osella, M.; Caselle, M. A curated database of miRNA mediated feed-forward loops involving MYC as master regulator. PLoS ONE 2011, 6, e14742. [CrossRef] [PubMed] 
144. Thakore, P.I.; D’Ippolito, A.M.; Song, L.; Safi, A.; Shivakumar, N.K.; Kabadi, A.M.; Reddy, T.E.; Crawford, G.E.; Gersbach, C.A. Highly specific epigenome editing by CRISPR-Cas9 repressors for silencing of distal regulatory elements. Nat. Methods 2015, 12, 1143-1149. [CrossRef] [PubMed]

145. Liu, S.J.; Horlbeck, M.A.; Cho, S.W.; Birk, H.S.; Malatesta, M.; He, D.; Attenello, F.J.; Villalta, J.E.; Cho, M.Y.; Chen, Y.; et al. CRISPRi-based genome-scale identification of functional long noncoding RNA loci in human cells. Science 2017, 355, aah7111. [CrossRef] [PubMed]

146. Dowdy, S.F. Overcoming cellular barriers for RNA therapeutics. Nat. Biotechnol. 2017, 35, 222-229. [CrossRef]

147. Mercatelli, N.; Coppola, V.; Bonci, D.; Miele, F.; Costantini, A.; Guadagnoli, M.; Bonanno, E.; Muto, G.; Frajese, G.V.; De Maria, R.; et al. The inhibition of the highly expressed miR-221 and miR-222 impairs the growth of prostate carcinoma xenografts in mice. PLoS ONE 2008, 3, e4029. [CrossRef]

148. Sicard, F.; Gayral, M.; Lulka, H.; Buscail, L.; Cordelier, P. Targeting miR-21 for the therapy of pancreatic cancer. Mol. Ther. 2013, 21, 986-994. [CrossRef]

149. Cardoso, A.L.C.; Simões, S.; de Almeida, L.P.; Plesnila, N.; Pedroso de Lima, M.C.; Wagner, E.; Culmsee, C. Tf-lipoplexes for neuronal siRNA delivery: A promising system to mediate gene silencing in the CNS. J. Control. Release 2008, 132, 113-123. [CrossRef]

150. Liu, Z.; Winters, M.; Holodniy, M.; Dai, H. siRNA Delivery into Human T Cells and Primary Cells with Carbon-Nanotube Transporters. Angew. Chem. Int. Ed. 2007, 46, 2023-2027. [CrossRef]

(C) 2020 by the authors. Licensee MDPI, Basel, Switzerland. This article is an open access article distributed under the terms and conditions of the Creative Commons Attribution (CC BY) license (http://creativecommons.org/licenses/by/4.0/). 